\title{
5 \\ Local Governing of Schools in Scandinavia-Between State, Market and Civil Society
}

\author{
Malene Thøgersen
}

\section{Introduction}

The education of future citizens is a fundamental welfare task, and therefore the school system plays a central role in relevant political debates (Arnesen and Lundahl 2006). In social democratic welfare states like the Scandinavian countries, the public sector is responsible for both financing and regulation in the field of education. The Scandinavian countries are also characterised by a high degree of decentralisation, with a large volume of welfare tasks carried out by the municipalities, including the responsibility for primary and lower secondary schools, which are the focus here (Kersting and Vetter 2003, 23; Baldersheim and Rose 2010; Nyhlén 2013, 158). However, municipalities are not the only providers of these schools. Nonprofit schools have a long history in the Scandinavian context. Moreover, increasing marketisation trends have affected the field. This trend has gone furthest in Sweden, where

\footnotetext{
M. Thøgersen ( $\square)$

Danish Institute for Non-formal Education, Aarhus, Denmark e-mail: malene.thogersen@vifo.dk 
for-profit providers today run schools side by side with public and nonprofit providers. Finally, across the Scandinavian countries, an increasing focus on freedom of choice has changed the conditions for local steering as well as citizens' opportunities to actively choose between different types of services, which can be seen as one important aspect of active citizenship (Chap. 1 in this book). Hence, the field of primary and lower secondary schools in Scandinavia is a complex mix of long historical traditions and recent trends from New Public Management (NPM) and market-based steering (Hood 1991; Donahue and Nye 2002). In other words, local governing in the field of schools takes place within a mix of tools and logics from both state, market and civil society.

This chapter will compare the field of primary and lower secondary schools in Sweden, Norway and Denmark and investigate the consequences of different national contexts for local governing in the field with a focus on different types of providers. The introductory chapters of this book leave no doubt that both the welfare mix and national legislation in the field of schools differ among the Scandinavian countries in spite of their belonging to the same welfare regime (Esping-Andersen 1990). The differences between the Scandinavian countries are evident in the various shares of welfare provided by private actors, as described by Sivesind in Chap. 2. In Chap. 3, Segaard and Saglie described the national legal framework for private providers, underlining important differences_-and similarities-between the countries when it comes to the private provision of primary and lower secondary schools.

In this chapter, the focus shifts to the local level, where national policies are implemented. The overall aim is to investigate the consequences of different national contexts for the local governing of schools in Sweden, Norway and Denmark by comparing both countries and different institutional sectors.

The empirical focus will partly be on the municipal level, with a focus on how national legislation is interpreted and implemented, and partly on the school level in order to investigate how national and municipal governing and steering are experienced and dealt with in practice. The analysis will focus on the following research questions: 
- How do municipalities implement national legislation, and which steering tools and types of regulation do they use?

- What are the consequences of national legislation and local steering and regulation for the schools?

- Do regulation and legislation promote or inhibit the development of a distinct profile of private schools compared with public schools? Are there any differences between the Scandinavian countries in this regard?

As is evident from these questions, the study is largely exploratory and has a strong empirical focus. All questions are addressed with a focus on comparisons across the Scandinavian countries and across different institutional sectors. The theoretical inspiration for the study is rooted in the literature on NPM, public steering and government-nonprofit relations. The empirical analysis will be based on data from case studies in two Swedish, two Danish and three Norwegian municipalities.

In the first part of this chapter, the theoretical background for the study will be presented. Afterwards, the characteristics of the welfare mix in the field of schools in the Scandinavian countries will be provided, including a view into the distinct development of alternatives to public schools. After a short presentation of data and methods, the empirical analysis will go deeper into the field of primary and lower secondary schools across the three countries, addressing the research questions above. This chapter concludes with a discussion of similarities and differences across countries and types of providers, including possible reasons for and consequences of these differences for future welfare provision in the field.

\section{Public Steering and Relations between Government and Nonpublic Services}

In the literature, much attention has been paid to various types of the welfare mix across countries (Gidron et al. 1992; Seeleib-Kaiser 2008; Alber 2010; Henriksen et al. 2012). However, relations between local governments and different types of local welfare providers in specific welfare fields are less well described empirically. In particular, there is a 
lack of attention on the role played by nonprofit organisations in local welfare provision (Pestoff 2009, 229). The concept of the welfare mix, which refers to new types of involvement by both for-profit and nonprofit actors in the welfare provision (Evers and Wintersberger 1990; Powell 2007; Anheier 2009; Dølvik et al. 2015) is therefore the underlying reason for investigating differences and similarities in the local governing of primary and lower secondary schools in Scandinavian countries. However, perspectives on public steering and governmentnonprofit relations will provide the theoretical background for the empirical analysis.

During the 1990s and 2000s, ideas and tools inspired by New Public Management (NPM) influenced steering of the public sector across countries and welfare regimes. However, one of the challenges with NPM and its focus on the market, freedom of choice and competition, turned out in many cases to be increasing fragmentation of the organisation and the steering of the public sector. The subsequent need for coordination and collaboration led to an increased focus on 'collaborative governance' in the literature on public management. It has been argued that there has been a shift from NPM towards collaborative governance, characterised by less control and based on the assumption that less control will pay off in terms of better performance (Donahue and Zeckhauser 2011, 32).

However, others have argued that empirical evidence for this trend is lacking and that rule-based and regulatory systems, which are also a part of NPM, are still dominant (Phillips and Smith 2011, 28). According to Phillips and Smith, there is a cross-country tendency towards more accountability and transparency, which typically requires more regulation. Hence, the focus on regulation has persisted in spite of a similar trend towards more collaboration across sectors, resulting in a dual pressure on the relationship not only between government and service providers - e.g. third sector organisations (Phillips and Smith 2011, 23), but also between government and for-profit actors who are increasingly involved in the service provision. In relation to the involvement of for-profit actors, the consequence is the tendency that more market creates a need for more regulation and thereby more state involvement (Petersen and Hjelmar 2013, 6; Dølvik et al. 2015, 106). 
The trends from NPM have been implemented in different ways across the three Scandinavian countries. A possible explanation for this can be found in the concept of institutional layering. The basic argument behind this concept is that although new tools and logics are incorporated into the agenda, they are often implemented on top of existing steering structures and historical traditions, resulting in large differences across countries and welfare fields (Thelen 2003). The impact of institutional legacies can, therefore, be seen as one possible explanation of the fact that the Scandinavian countries have implemented a more moderate version of NPM than countries with liberal welfare regimes (Politt and Bouckaert 2011, 64).

However, the impact of different institutional legacies can also be an important explanatory factor for the differing roles played by nonprofit providers across the Scandinavian countries. As it is argued in neo-institutional perspectives on nonprofit-government relationships, nonprofit organisations are largely a product of the institutional environment surrounding them (Smith and Grønbjerg 2006, 235).

In Scandinavian countries, there has been a long tradition of close collaboration between sectors, in spite of the government dominating welfare systems (Henriksen and Bundesen 2004). Traditional theories of nonprofit government relations-e.g. the literature on government, market and voluntary failures (the three-failures theory) which focus on how each sector compensates for each other's weaknesses-have not left much room for this kind of close collaborative relationship between the sectors (Steinberg 2006). However, increasing complexity in modern welfare states has prompted collaboration between sectors across countries and welfare regimes. Recent literature even suggests that government-nonprofit cooperation today is necessary to obtain effectiveness (Salamon and Toepler 2015).

The literature on public governance distinguishes between different ideas or ideal types of governance. A common distinction is between hierarchy, market and network (Jørgensen and Vrangbæk 2004; Meuleman 2008; Greve and Ejersbo 2013, 16). The three types of governance are not mutually exclusive. It is possible to find elements from all three types at the same time, although one of the types will often dominate (Jørgensen and Vrangbæk 2004, 83). 
In hierarchical steering, rules and authority are the central elements. In market-based steering, order is to some extent left to market forces-for instance, through freedom of choice. Finally, in network-based steering, order is made through interaction and dialogue between interdependent actors in the system (Jørgensen and Vrangbæk 2004, 12).

The three ideal types can be reflected in municipal steering strategies. In a study of local governing of Swedish schools, Nyhlén (2013) identified three different types of local steering strategies in the relationship between municipalities and schools in a system with freedom of choice: control, competition and collaboration. Control-based steering strategies imply that the municipality takes initiatives to control the schools. Competitive steering strategies are at play when the municipality's awareness of competition is reflected in its steering. For instance, the municipality may seek to profile the public schools to prevent too big a flow of pupils to private schools-e.g. through marketing initiatives. Finally, collaborative steering strategies imply that the municipality actively seeks collaboration with the schools. According to Nyhlén, steering strategies vary across municipalities, and the different models affect the characteristics of the relationship between municipalities and schools (Nyhlén 2013, 157).

The three types of steering strategies identified by Nyhlén serve as a framework for the empirical analysis in this chapter (Table 5.1). However, it is important to note that control, collaboration and

Table 5.1 Analytical framework

\begin{tabular}{|c|c|c|c|}
\hline $\begin{array}{l}\text { Ideal types of } \\
\text { governance }\end{array}$ & Hierarchy & Market & Network \\
\hline $\begin{array}{l}\text { Steering } \\
\text { strategies }\end{array}$ & $\begin{array}{l}\text { Control-based } \\
\text { steering } \\
\text { strategies }\end{array}$ & $\begin{array}{l}\text { Competitive } \\
\text { steering } \\
\text { strategies }\end{array}$ & $\begin{array}{l}\text { Collaborative } \\
\text { steering strategies }\end{array}$ \\
\hline Elements & $\begin{array}{l}\text { Rules } \\
\text { Inspections }\end{array}$ & $\begin{array}{l}\text { Marketing } \\
\text { initiatives } \\
\text { Promotion of } \\
\text { schools }\end{array}$ & $\begin{array}{l}\text { Meetings and other } \\
\text { formal relations } \\
\text { Informal relations }\end{array}$ \\
\hline Degree & $\begin{array}{l}\text { Degree of } \\
\text { control-based } \\
\text { steering }\end{array}$ & $\begin{array}{l}\text { Degree of } \\
\text { competitive } \\
\text { steering }\end{array}$ & $\begin{array}{l}\text { Degree of } \\
\text { collaborative } \\
\text { steering }\end{array}$ \\
\hline
\end{tabular}

Inspired by Jørgensen and Vrangbæk (2004), Greve and Ejersbo (2013), and Nyhlén (2013) 
competition are seen as analytical categories, not as an explicit choice of strategy made by the municipalities. The aim of using these categories is to structure the analysis and provide room for structured comparisons across countries and types of providers. Within each of the three analytical categories, the analysis will focus on concrete elements of steering but also the degree of steering: The extent to which elements of control, competition and collaboration are evident in the local governance of primary and lower secondary schools.

\section{The Welfare Mix and Characteristics of the Field of Schools in Scandinavia}

In Denmark, Norway and Sweden, the public sector accounts for the vast majority of primary and lower secondary schools, but private providers also play a role. However, there are interestingly different trajectories between the countries when it comes to the scope and type of private provision.

In Denmark, primary and lower secondary schools are either public or run by nonprofit providers, and there is a strong historical tradition of nonprofit schools. This tradition is rooted in the constitution, underlining compulsory education but not compulsory school attendance.

Regarding choice, all children belong to a public district school and have the right to attend this school, but it is possible to choose a nonprofit school or another public school within or outside the municipality, when available (Law on Public Schools, LBK 665). During recent years, there has been an increase in the number of nonprofit schools, from 460 in 2000 to 526 in 2011. Nonprofit schools also represent an increasing share of the total number of pupils; in 2011, their share was $15 \%$ (Thøgersen 2015).

Nonprofit schools in Denmark are subsidised by the state. The level of funding has been reduced during recent years, corresponding to $71 \%$ of the average expenses per pupil in public schools in 2015. However, municipalities pay the state for each pupil in nonprofit schools, ${ }^{2}$ and they therefore still constitute expenditures for the municipalities. 
Nonprofit schools must charge the parents to receive public funding but are free to decide the level of parental payment.

Compared to many other types of nonprofit welfare providers in Denmark, nonprofit schools have some special privileges: Parents have the right to establish a new school and acquire public funding as long as the school fulfils national legal requirements. Moreover, nonprofit schools do not operate through a contract with the municipality, and they have a high degree of freedom when it comes to the content and structure of teaching and the running of the school in general. As an example, nonprofit schools have the right to decide which pupils they accept, and they are not obliged to do national tests or offer final exams. The school boards have the responsibility for both the finances and all other issues associated with the operation of the schools (Law of Independent and Private Schools, LBK 917).

In contrast, public schools are highly regulated at both the national and local level, and municipalities have full responsibility for public schools (Bogason 2001). The degree of national regulation has increased during recent years-for instance, through the implementation of national tests. However, municipalities still have many steering options (Law on Public Schools, LBK 665).

In Norway, there is also compulsory education and no compulsory school attendance. Like in Denmark, primary and lower secondary schools are run by municipalities or nonprofit providers. In the 2013-2014 school year, there were 195 nonprofit schools in Norway. This represents a doubling of the number since 2002-2003. However, most of the schools are quite small. In the same period, the share of pupils in nonprofit schools had only risen from slightly less than $2 \%$ to about $3 \%$ (Utdanningsdirektoratet 2014, 16). Consequently, nonprofit schools are still a marginal supplier compared to public schools.

To establish a nonprofit school, one must apply to a national directorate. For an application to be approved the school must fulfil certain criteria; among others, it must represent a 'recognised' alternative to public school - typically by being based on certain pedagogies, religious faiths or international dimensions. The municipality where the potential school is located is invited to give its opinion on its establishment, but the national directorate makes the final decision. 
After their establishment, nonprofit schools are only regulated by national rules and regulations. Like in Denmark, the school boards have responsibility and authority over all major aspects of the operation of the schools, including budgets, hiring and other strategic decisions. However, Norwegian nonprofit schools are obliged to have objective criteria for selecting pupils and cannot reject certain pupils. By comparison, public schools are integrated into the municipality and are thus subject to municipal policies and regulations.

Nonprofit schools receive $85 \%$ of the funding level of municipal schools. The schools can thus charge the parents for the remaining $15 \%$, but no more (Seegaard 2015, 40). The nonprofit schools get their funding directly from the state, and this money is deducted from the transfers that municipalities receive from the state. Thus, municipalities indirectly pay nonprofit schools for their pupils. Each municipality can decide if it wants to have user choice among the public schools. In all cases, the pupils are entitled to attend their local public school, but parents can choose a nonprofit alternative when available.

Sweden is similar to Denmark when it comes to the share of pupils attending private schools. Thirteen percent of the total number of pupils attended private (nonprofit or for-profit) schools in 2011. However, Sweden stands out from the two other countries because of a law that permits the transfer of profits to owners of primary school services with public funding. In 2013, the number of private schools was 792, which means that $16 \%$ of the schools were run by a private provider (nonprofit or for-profit). This number represents an increase compared to the situation in 2009 (Skolverket 2014). Across a longer time span, the increase has been even more considerable: At the end of the 1970s, less than 1\% of the children of school age attended private schools (Lindström and Wijkström 1995, 20). Today, the majority of private authorities are joint stock companies, while nonprofit organisations play a limited role (Skolverket 2014).

Developments towards a 'welfare mix' in the Swedish primary and lower secondary school system began in the early 1990s. Before then, private actors mainly operated in a marginal part of the systemboarding schools. These schools were allowed by the government since they could provide an alternative, which the public schools could not. 
In 1992, the non-socialist government had the opinion that parents should be able to choose between different types of providers. To make this possible, it was decided that municipalities had to pay private providers of schools at least $85 \%$ of the average cost per pupil attending a public school (Prop. 1991/92: 25). According to newer legislation, municipalities must treat public and private schools equally, i.e. private schools must obtain the same amount of money per pupil as public schools (Prop. 2008/09: 171).

A prerequisite for obtaining public funding for a private school is permission by the central state authority, the Swedish Schools Inspectorate. In the beginning, municipalities had little influence on this decision by central authorities. At present, municipalities have more influence but no formal veto on the final decision (Jarl and Rönnberg 2010, 81).

In spite of the differences between the three Scandinavian countries, a common feature is that approval for the establishment of private schools is a national task, but the standards and requirements that should be fulfilled to obtain this approval vary between the countries. Local governments do not have a formal say on the number of private schools in the municipalities, which highly affects steering possibilities in the field.

Freedom of choice is another common feature across the Scandinavian countries. In Denmark, parents have always had the right to choose private schools instead of public schools; and in 2002, freedom of choice among public schools was implemented. In Sweden, user choice was implemented through 'Friskolereformen' in 1992, which also made it possible to include for-profit actors in the provision of for-profit schools. In Norway, the possibility of choosing between different public schools varies between municipalities. However, if a nonprofit school is available, it is always possible to choose this school instead of a public school.

An important difference is that a common national law regulates all types of primary and lower secondary schools in Sweden, regardless of the type of provider. In contrast, nonprofit schools have their own law in both Denmark and Norway (Seegaard 2015, 94). This fact might be one of the reasons why conditions for different types of providers vary less in Sweden than in Denmark and Norway. For instance, private schools in Norway and Denmark are obliged to charge parental payment to get 
financial support from the state. In Sweden, all types of primary and lower secondary schools are provided free of charge for the users. However, there are also some differences between Denmark and Norway, as private schools have a higher degree of freedom regarding their curriculum and admissions in Denmark than in either Norway or Sweden (Segaard and Saglie, Chap. 3).

Altogether, in spite of their belonging to the same welfare regime, the three Scandinavian countries vary in a number of ways when it comes to the field of schools-regarding both the welfare mix and the national regulation the field. The following sections will take an empirical and analytical look into how these differences and similarities between countries and providers are reflected in the local governing of schools, with specific focus on elements of control, competition and collaboration.

\section{The Case Study Design}

The analysis will be based on case studies at the municipal level in Sweden, Norway and Denmark. Seven municipalities were selected for the case studies, and similar data gathering strategies and interview guides were used across countries and municipalities. The empirical data consist of qualitative interviews at both the municipal and school level, combined with written documents. A more detailed description of the selection of municipalities and schools is provided in the appendix to Chap. 1 in this book, including an overview of selected municipalities, schools and interviewees.

In each municipality, at least two schools were selected: One municipal and one private (nonprofit or for-profit). The case study design allowed for comparisons between different types of providers in the same local communities, thus controlling for many contextual factors. The analytical dimensions in this chapter will be structured, qualitative comparisons (Sivesind 2007) of data from interviews with actors in similar positions between countries and institutional sectors: public, nonprofit and for-profit schools. 


\section{Local Steering Trends in the Field of Schools}

The following analysis will focus on local steering and types of regulations at play in the case municipalities in the field of primary and lower secondary schools. The analysis will be structured by the three analytical categories: control, competition and collaboration (Nyhlén 2013), corresponding to the three ideal types of governance: hierarchy, market and network (Jørgensen and Vrangbæk 2004; Meulenman 2008). The focus in the analysis will primarily be at the municipal level. However, experiences and practices at the school level will also be included.

\section{Elements of Control}

When it comes to elements of control in the local governing of schools, there are large differences across the different types of providers in the study. In all three countries, municipalities have very few steering possibilities when it comes to the number of private schools they contain. Private schools can be established as long as they live up to the national standards.

In the Danish case, some of the interviewees at the municipal level considered this lack of control problematic:

They [the nonprofit schools] have become a natural part of the school system. However, they do give rise to challenges related to steering and planning. (Administrative leader, DK, 8.10.2013)

In contrast to many other welfare areas, there are no contracts between municipalities and nonprofit schools; which is, for instance, the case for nonprofit daycare. Moreover, there are very few restrictions in terms of inspections, which can either be conducted by the schools themselves or by an inspector chosen by the schools (LBK 917). The limited control is also evident in cases where a pupil is expelled from a nonprofit school and it is up to the municipality to find a suitable alternative. Finally, it can be a challenge in relation to efficient planning as, for example, when a nonprofit school is established as a consequence of the closing of a 
municipal school, and the municipality thereby does not achieve any cost reduction (Interview, administrative leader, DK, 18.12.2013).

In contrast to nonprofit schools, municipalities have a lot more control of public schools. Although national legislation sets the overall framework, there is still room for municipal steering and control. Responsibility for the inspection of public schools rests at the national level. However, municipalities typically make their own quality reports to document and follow the performance of the public schools (Interviews, administrative leaders, DK, 8.10.2013, 18.12.2013). Municipalities also have financial control of public schools and are free to decide both the number of schools and the limits of school districts. However, the freedom of choice also limits the degree of municipal control over public schools. Many parents use their freedom of choice, and there is a high degree of volatility between the schools. In one of the case municipalities, $56 \%$ of the pupils attend their district school, while the rest attend either a nonprofit school or another public school (Faaborg-Midtfyn kommune 2012). In some cases, this volatility can make it difficult to sustain schools in less populated areas:

I find it problematic in relation to service in less populated areas, I really do. Both in the field of schools and in the field of daycare. If many pupils - or in some cases just a few - choose another school, they remove the basis for a school or a daycare institution. (Political chair of committee, DK, 4.10.2013)

At a more detailed level, municipalities have the option to promote and prioritise specific initiatives at the schools: An option that is used in both case municipalities. In Norway, the municipalities also experience that the possibility of establishing nonprofit schools can challenge efficient planning. For instance, it is difficult for the municipalities to save costs through the closing of small schools if parents choose to establish a nonprofit school instead:

In the long run we have to look at the school structure in the municipality; it is a question of how small we can become [...] It is not like we necessarily have to close a school, but we can think differently about our 
operation. But then the Montessori phenomenon is awaiting and can take over, and that becomes an expensive experience. Having two nonpublic schools in the municipality. (Administrative leader, N, 12.02.2014)

In this particular municipality, Løten in Norway, the nonprofit school has 45 pupils living within the municipality, while the rest come from neighbouring municipalities. According to the administrative leader, these 45 pupils could easily be integrated in the municipal school with few extra costs. In Steinkjer, one of the other Norwegian case municipalities, the municipal government decided to merge two public schools and has afterwards fought the establishment of a new Montessori school on the outskirts of the municipality. In this case, the Norwegian national directorate has so far accepted pleas from the municipality to prevent the school from being established. This will often be the case if the municipality can plausibly argue that a private school will weaken the basis for the public school. However, the municipality does not formally have a veto.

The public schools, by comparison, are entirely integrated within the municipality. Limited only by national regulations, the municipalities can run their schools as they wish. This includes decisions about school districts as well as the extent of user choice among public schools. Of the selected municipalities, Løten has no user choice, while parents in Steinkjer and Asker are able to choose between schools. In addition, the municipalities can decide the priorities of the schools. As an example, in Asker, the municipality has defined 15 detailed measures that the schools need to report on, in addition to both compulsory national tests and tests implemented by the municipality. Taken together, these targets and tests leave little room for local priorities at the schools.

Also in Sweden, municipalities have fewer steering possibilities and less control of private schools (nonprofit or for-profit) than public schools. However, the differences in the degree of control between different types of providers are less evident than in Denmark and Norway. One of the reasons for this is that all types of schools in Sweden are regulated by the same law. Highest in the regulation hierarchy is the Education Act, a law regulating the foundations for the Swedish education system. This act is followed by curricula adopted at the central level, which regulate the content of education in more detail. One of the requirements for 
obtaining permission for establishing a school is that it fulfil all the requirements of the law and curricula. In addition to central steering through national law and curricula, evaluations are performed by a central state authority, i.e. the Swedish Schools Inspectorate. This authority has the most far-reaching mandate since they can shut down a school because of an inspection. This goes for all schools regardless of provider.

Municipalities are heads of the primary and lower secondary schools, a task that implies a financial responsibility. The municipality calculates the price per pupil in a public school, and private schools then receive a corresponding compensation. In the municipalities investigated, meetings occur between the administration and private schools concerning the exact figure. However, these meetings do not concern the budget at each school nor how the money is used for different activities. This is an important difference compared to meetings held with the public schools, covering additional aspects. For instance, there is dialogue concerning areas for improvement at a particular school:

What is good at the school, what is less well and which areas of development should be prioritised and how. (Administrative leader, S, 9.4.2015)

It could be asked whether the financial responsibility of the municipality for private schools actually constitutes a steering tool. According to one of the politicians interviewed, the national act is very clear on this issuecompensation should be the same for all types of schools, and therefore there is not really that much to discuss (Interview, social democratic politician, S, 9.4.2014).

Besides financial responsibility, municipalities have their own guidelines targeting schools. In Östersund, these guidelines include a mandate that all pupils leaving primary school should be qualified to apply to a secondary school, that the municipality should have a variety of programmes, and that staff should have a teaching licence and access to further education (Östersunds kommun 2013). Similar guidelines exist in Sollentuna, such as equal treatment of schools regardless of whether the provider is private or public, that no pupil should be a victim of bullying, and that a higher share of pupils should have their first choice of school approved (Sollentuna kommun 2008). 
Formally, the guidelines only apply to public schools. However, in Sollentuna, private schools have voluntarily chosen to adopt them. In Östersund, the head administrator simply stated that there are no formal local guidelines from the municipality that apply to private providers (Interview, administrative leader, S, 9.4.2015).

In each of the municipalities, schools are also being governed through local evaluations. However, the target groups vary between municipalities. In Östersund, evaluations performed by the local administration only cover public schools and their fulfilment of learning requirements according to central regulation. Additionally, evaluations are made about what the schools are good at and how better activities can be developed. Part of this work is based on questionnaires sent out to both pupils and parents (Interview, administrative leader, S, 9.4.2014).

In Sollentuna, evaluations performed by the municipal administration targets all schools regardless of provider. One example of this is a questionnaire sent out to parents concerning the quality of the school. The result of the evaluation is displayed through the municipality's own website, making it possible for citizens to compare different schools (Interview, conservative politician, 13.12.2013; social democratic politician, S, 16.12.2013).

Summing up the Swedish case, private schools have the option to choose whether to follow municipal guidelines or not. Whether public evaluations only cover public schools or all schools also varies between the case municipalities. However, municipalities still have less control over private schools than public schools, specifically when it comes to financial control and local school priorities. Another important point from the Swedish case is that there are no differences in the degree of steering across different types of private providers. Hence, both for-profit and nonprofit providers are subject to the same regulations.

\section{Experiences at the School Level-Elements of Control}

The differences across providers in relation to elements and the degree of municipal control are also reflected in the schools' experiences and 
perceptions. The quote below from a nonprofit school leader in Denmark shows that this high level of self-determination and potential to create a school based on specific values, distinct from public schools, is valued. It is even underlined that it would be appropriate if nonprofit schools were obliged to develop a distinct profile:

I find the freedom fantastic. I really do. And I do not understand that you do not want to make other types of demands. For instance, when we have the privilege of receiving financial support from the state, I think we ought to have a pedagogical profile where we do something different. (School leader, nonprofit school, DK, 5.2.2014)

In Norway, nonprofit schools are obliged to have a distinct profile, but the nonprofit schools still value the low level of control that sometimes frustrates the municipalities. As one school leader explained:

My experience is that we have a lot of freedom, absolutely. Of course, we must follow the law, but besides that I think we pretty much have freedom when running the school [...] we are sort of our own little municipality, you know. Therefore, it is somewhat different; we do not have a school director to report to. (School leader, nonprofit school, N, 12.02.2014)

At the same time, this freedom exists within certain confines. According to national law, the schools must document how they are different from public schools. In the case above, the school has a Christian foundation. This framework narrows the amount of freedom in daily operations. As an example, the school only hires Christian, heterosexual employees. This demonstrates their level of freedom since a public school could never have such a policy.

Also in Sweden, private school leaders experience a high degree of freedom. The perception is that steering primarily comes from the national level and to a lesser extent from the municipality. One of the school leaders at a private school in Östersund concluded that there is no steering taking place, other than the money received from the municipality. Instead, the perception is that the school is almost entirely being 
governed from the central level through laws and regulations (Interview, school leader, for-profit school, S, 4.4.2014).

The perceptions above, across countries, stand in sharp contrast to the view held by school leaders at public schools. In Denmark, Norway and Sweden, the perception is that the level of steering and control from both the national and local level has increased over recent decades. A school leader of a public school in Norway described this development:

This has changed a lot since I began. When I became school leader, there were two and a half people [in the municipal administration] who worked with school issues, and we had no school manager. Then, everything was left to us and at the same time, we received little support. Now, we are in a situation where I personally find that too many people work to support us, because how it works is that they make a list of how things should be, but then they do not have to do anything about it, if you see what I mean? (School leader, public school, N, 21.11.2013)

A school leader in one of the Danish case municipalities described how too much steering regarding local issues at the school can be problematic, because it leaves the school with less influence over daily life-for instance, regarding the completion of practical tasks at the schools. Earlier, such tasks had been completed by the school itself, but now it was a municipal task:

Pedagogical leadership also includes the physical environment, and now we can see that they let the place be run down. We had a very nice new wooden terrace, but now it is full of water and leaves. Something that you would never accept at home without doing something about it, but all I can do is call and call [...] It is bad pedagogy towards the children. Why should they clean up then? (School leader, public school, DK, 9.1.2014).

Also in Sweden, a public school leader described how municipal steering implies detailed financial regulations on how to spend the budget for different parts of the operation of the school, leaving the schools with limited possibilities for local decisions (Interview, school leader, public school, S, 4.4.2014). 


\section{Summing up_Elements of Control}

The results of the analysis of elements of control in the local governing of primary and lower secondary schools are summarised in Table 5.2.

It is evident in the table that municipalities across Scandinavian countries have few steering possibilities when it comes to private providers, regarding both financial and quality control. This is particularly evident in the Danish and Norwegian cases. The limited degree of control goes furthest in Denmark, where it is up to nonprofit schools to decide which pupils to accept. In Sweden, the degree of control is also relatively low, but the differences between providers are limited by common national regulation of all types of schools. This also implies that there are no differences in the municipal steering of nonprofit and for-profit schools. All schools have the same level of financial resources and have to live up to the same curriculum. Moreover, the municipal control of private schools in Sweden varies between the case municipalities because of different procedures regarding guidelines and evaluations.

Table 5.2 Elements of control in the local governing of schools

\begin{tabular}{|c|c|c|}
\hline & Elements of control & $\begin{array}{l}\text { Degree of } \\
\text { control }\end{array}$ \\
\hline \multicolumn{3}{|l|}{ Denmark } \\
\hline $\begin{array}{l}\text { Nonprofit } \\
\text { schools }\end{array}$ & $\begin{array}{l}\text { No municipal financial control } \\
\text { No municipal quality control }\end{array}$ & Low \\
\hline $\begin{array}{l}\text { Public } \\
\text { schools }\end{array}$ & $\begin{array}{l}\text { Financial control through municipal budgets } \\
\text { Quality control through quality reports and } \\
\text { inspections }\end{array}$ & High \\
\hline \multicolumn{3}{|c|}{ T- } \\
\hline $\begin{array}{l}\text { Nonprofit } \\
\text { schools }\end{array}$ & $\begin{array}{l}\text { No municipal financial control } \\
\text { No municipal quality control }\end{array}$ & Low \\
\hline $\begin{array}{l}\text { Public } \\
\text { schools }\end{array}$ & $\begin{array}{l}\text { Financial control through municipal budgets } \\
\text { Quality control through tests, surveys, quality } \\
\text { reports and inspections }\end{array}$ & High \\
\hline \multicolumn{3}{|c|}{ r } \\
\hline $\begin{array}{l}\text { Private } \\
\text { schools }\end{array}$ & $\begin{array}{l}\text { Limited financial control through municipal } \\
\text { budgets, but no financial supervision } \\
\text { Quality control through guidelines* and surveys* }\end{array}$ & Medium/Low* \\
\hline $\begin{array}{l}\text { Public } \\
\text { schools }\end{array}$ & $\begin{array}{l}\text { Financial control and quality control through } \\
\text { guidelines and surveys. }\end{array}$ & High \\
\hline
\end{tabular}


In contrast, municipalities exercise a rather high level of control when it comes to public schools, with respect to both financial control and quality control. Although national legislation sets the overall framework, there is still room for municipal steering and control, which takes place in all three Scandinavian countries. Moreover, the experience has been that the degree of regulation and control has increased during recent years, from both the national and local level.

\section{Elements of Competition}

Given the freedom of choice between different types of schools, elements of competition are an inevitable part of the municipal steering of primary and lower secondary schools in Denmark, Sweden and Norway.

In Denmark, local party programmes in both municipalities reveal relatively broad support for freedom of choice and various types of welfare providers. In spite of this and the general respect for the historical role of nonprofit schools, there has been a lot of focus on quality development in public schools to prevent parents from deselecting public schools and to make public schools as attractive as possible:

There is no resistance towards nonprofit schools, but of course politicians wish to make public schools as attractive as possible to prevent a deselection of public schools. (Administrative leader, DK, 18.12.2014)

The focus on public schools is also evident in local party programmes; in most of them, nonprofit schools are hardly mentioned, even in Faaborg-Midtfyn where almost one-third of the pupils attend nonprofit schools. Both political and administrative leaders underline that nonprofit schools are seldom discussed politically. As an exception to this general picture, there was a proposal on one theme day on how to prevent people from choosing nonprofit schools'. The proposal was not accepted, and the day ended by focusing on how to profile public schools (Faaborg-Midtfyn Kommune 2012; Political chair of committee, DK, 4.10.2013). However, the example shows that some politicians find it problematic that so many parents choose nonprofit schools. The attitude 
towards nonprofit schools varies between political parties. According to an administrative leader, the classical political divide between left-wing and right-wing parties can also be identified in the field of schools. The Liberal and Conservative parties are generally more in favour of nonprofit schools and freedom of choice than left-wing parties (Interview, administrative leader, DK, 8.10.2013). However, across interviewees at the municipal level, there was some scepticism about the special privileges of nonprofit schools. Many interviewees had the opinion that when nonprofit schools opt for a free status, they cannot expect the same privileges as public schools. Moreover, some of the interviewees perceived unequal competition because nonprofit schools are allowed to refuse pupils, resulting in the risk of an unequal society with A- and B-schools (Interview, administrative leader, DK, 8.10.2013).

Also in Norway, nonprofit schools receive very limited attention in local party programmes. Primary and lower secondary schools are one of the core tasks of the municipalities, and therefore all programmes have policies for public schools. However, in all municipalities, only a minority of the parties mention the nonprofits. According to the interviewees at the municipal level, the only time the city councils debates about nonprofit schools is when the municipality is asked to voice its view on the establishment of a new school. One of the founders of the nonprofit school in Steinkjer experienced a negative attitude from the municipality when the school was in the process of being established 10 years ago:

When we came up with the idea of establishing something in direct competition with the public providers, then the attitudes changed. That was a big surprise really [...] There was so much opposition to this. (Founder, nonprofit school, N, 13.02.2014)

It is evident from this statement that the founders experienced intense opposition to the establishment of their nonprofit school. Today, however, the school has been functioning for 10 years and, due to its limited size, its existence has not prompted the municipality or the public schools to change their behaviour. The following statement from an 
administrative leader in Steinkjer illustrates how the municipality sees nonprofit schools:

We think they are a good supplement. I absolutely think there is nothing negative about it. It is most important that the children learn and do well at the Montessori school. That is the most important: the individual child. It is no point for me that all shall attend the public school. I just want it [the public school] to be good enough, so that no one wants to leave it. That is what I want. I think it is great that we have such a school, with regard to happy living. We might attract some [new residents] because we have an alternative to the public school. (Administrative leader, N, 20.02.2014)

This quote shows that municipalities want to offer high standards in order not to lose pupils. At the same time, the leader recognises that the nonprofit school offers something different, which can be attractive for some citizens.

As in Denmark, municipalities in Sweden cannot influence the degree of privatisation within education. If a private provider chooses to establish a school, they are free to do so, as long as the central authority grants their application. Nevertheless, the Swedish case municipalities cope with this new context of marketisation in different ways. These differences may reflect different degrees of political support for privatisation evident in the two municipalities.

In Östersund, the majority is foremost represented by the Social Democratic Party, and as such, the municipality has a negative attitude towards private providers within education. Every time the question of the establishment of a private school has been discussed in the committee of education, the Social Democratic Party has been against it. The chair of the committee declared in an interview that were his party to decide, only one alternative would be evident - the public one (Interview, social democratic politician, S, 9.4.2014). However, municipalities cannot stop the establishment of private schools, as long as they are approved by national authorities. The non-socialist parties in the committee hold the opposite view. According to a member of the committee representing the 
Liberal Party, there should be more private providers and alternatives to choose from (Interview, liberal politician, S, 9.4.2014).

In Sollentuna, a municipality governed by non-socialist parties, the majority is clearly in favour of freedom of choice, while the opposition parties are more reluctant. The chair of the committee for education, representing the Moderates (Conservative Party), stated that the majority of members within the committee welcome new providers of schools to Sollentuna. The most important goal for them is that schools within the municipality have good quality regardless of provider (Interview, conservative politician, S, 13.12.2013).

The opposition parties are more hesitant about privatisation. A member of the committee, representing the Social Democratic Party, remarked that their position depends on the situation in each district of the municipality. If a new private school would pose a threat to an existing public one, then the party would vote 'no' (Interview, social democratic politician, S, 16.12.2013).

Different attitudes towards the welfare mix in Östersund and Sollentuna might have consequences for the practice of freedom of choice. In Sollentuna, the system of freedom of choice is promoted more clearly than in Östersund through a special website. During January and February each year, every parent makes a choice of school, regardless of the type of provider, on the municipality's website. Connected to this site are surveys which allow parents and pupils to compare different alternatives regardless of provider.

In Östersund, there are no similarities to the system practiced in Sollentuna. Instead, pupils automatically receive a place at the public school closest to their home (i.e. the proximity principle). If pupils and their parents prefer a private alternative, they must make a direct application to that particular school. In March each year, the private schools inform the municipality of how many and which pupils they have accepted. This makes it possible for the municipal administration to adjust their figures for the number of pupils in public schools.

In sum, Sollentuna actively promotes the system of freedom of choice, while Östersund practises a more traditional model in which pupils are placed at schools according to the principle of proximity. An interpretation of this difference is that Sollentuna acts as a facilitator of freedom 
of choice, making it easier for their citizens to compare, and then choose an appropriate school. The method practiced in Östersund, on the other hand, indicates that the municipality perceives itself as one type of provider on a competitive market, rather than as a facilitator of freedom of choice.

\section{Experiences at the School Level-Elements of Competition}

When it comes to experiences at the schools regarding elements of competition, the study shows some differences between the Scandinavian countries. In both Denmark and Sweden, the perception of the schools is that there is a competitive situation between them, particularly in areas with many schools within a limited geographical area.

In the Danish case, nonprofit schools see the primary focus of their municipalities to be on public schools, while very little attention is paid to them, even in Faaborg-Midtfyn, a municipality with a very high share of pupils in nonprofit schools:

Politically, we do not have first priority here in the municipality. (Board member, nonprofit school, DK, 12.2.2014)

No, we would be lying, if we said so. It is evident that public schools are given greater priority. (Board member, nonprofit school, DK, 12.2.2014)

Yes, and especially here in the local community, we attract the same pupils as the public school. It is not very popular in the municipality that we attract so many pupils. (Board member, nonprofit school, DK, 12.2.2014)

The interviews clearly indicate that the nonprofit schools would like to be a more valued part of the school system in the municipality, and that the competitive situation is one of the reasons why municipalities pay very little attention to nonprofit schools. The interviews also show that nonprofit schools are very focused on being a high-quality alternative to the public schools. 
Also in Sweden, all school leaders are well aware of the competition taking place between units. This is particularly evident at those schools that have or have had problems with attracting or keeping pupils. At one of the private schools in Sollentuna, the school leader believed that proximity was the most important factor when choosing a school. However, reputation was another important factor, with a negative or positive impact on the number of applicants (Interview, school leader, for-profit school, 3.4.2014). At one of the private schools in Östersund, pupils come from all parts of town. According to the school leader interviewed, this is due to the reputation of the school:

People know the good environment, the good teachers, who work here and the results of it. (School leader, for-profit school, S, 4.4.2014)

Because of this reputation, there is no need to advertise for the school and its activities. At one of the public schools in the same town, there has been an outflow of pupils to private alternatives. To better understand this development, the school carried out a survey about the parents' motives for changing the school for their child. Many of the parents responded that they did not believe the public school was good enough for their child due to insufficient quality. The public school responded by not only improving quality, but also by improving communication about pedagogical activities taking place and the ideas behind them (Interview, school leader, public school, S, 4.4.2014). These examples show that the competitive situation can influence priorities locally at the schools.

The Norwegian case stands out from the other Scandinavian countries when it comes to the schools' perception of and experiences with competition. Neither the nonprofit nor the public schools perceived the other schools as competitors. For the public schools, the nonprofit schools are not big enough to pose a threat, as they cannot attract sufficient numbers of pupils to challenge the public schools. The nonprofit schools do not have the same natural pool of pupils who attend the school because they live close by, but they still do not experience competition-for instance as stated by this school leader of the Waldorf School: 
I do not see our school as in a competition because we constitute a niche. We use an entirely different curriculum, we are an alternative, and for me that is motivation enough. Because I think we have a right to exist, since we are an alternative that I have experienced through many years has been important for many people. And I see no reason why we should not in the future continue to be important for many people. Not all, but for many, in sum over time, there are many people who have experienced crucial positive development by being able to choose something different from the public school. Not because the public school has been bad, but because this school has been suitable for them. (School leader, nonprofit school, N, 10.12.2013)

According to this claim, the degree of competition is perceived to be low because the nonprofit school represents a niche that attracts other types of pupils. This example shows that a high level of distinctiveness between providers might limit the level of competition.

\section{Summing up_Elements of Competition}

The results of the analysis of elements and degree of competition are summarised in Table 5.3.

Parents' option to choose between different types of schools will often lead to a certain level of competition. As the table shows, elements of competition in the field of schools are evident in both Denmark and Sweden. In Denmark, the municipalities actively seek to promote public schools to prevent deselection. The competitive situation is also experienced by the schools - in particular in one of the case municipalities,

Table 5.3 Elements of competition in the local governing of schools

\begin{tabular}{lll}
\hline & Elements of competition & $\begin{array}{l}\text { Degree of } \\
\text { competition }\end{array}$ \\
\hline $\begin{array}{l}\text { Denmark } \\
\text { Norway }\end{array}$ & $\begin{array}{c}\text { Nonicipal strategy for promoting public schools } \\
\text { but cater to different segments }\end{array}$ & $\begin{array}{l}\text { Medium } \\
\text { Sweden }\end{array}$ \\
$\begin{array}{c}\text { Schools experience competition regardless of } \\
\text { municipality and type of provider. The role of the } \\
\text { municipal administration in this competition differs }\end{array}$ & Low \\
\hline
\end{tabular}


where the geographical distance between the schools was limited. Also in Sweden, both municipalities and schools are aware of the competitive situation. However, the municipalities deal with the situation in different ways. While one of the municipalities actively promotes freedom of choice, the other municipality has a more passive approach. Interestingly, the degree of competition is far lower in Norway, where the perception at both levels is that nonprofit schools do not pose a threat to public schools, because of both their limited size and their distinctiveness.

\section{Elements of Collaboration}

Across the Scandinavian countries, the analysis shows that the degree of collaboration between municipalities and private schools is very limited, while there is more collaboration when it comes to public schools. However, there are some differences between the countries, regarding both the content and level of collaboration.

In the Danish case, elements of collaboration between municipalities and nonprofit schools are very limited in both municipalities, according to the administrative leaders. Due to state funding of the schools, there are no financial relations between nonprofit schools and the municipalities, and none of the municipalities have formal meetings with representatives from nonprofit schools (Interviews, administrative leaders, DK, 8.10.2013, 18.12.2013). The limited degree of collaboration is closely related to lack of steering possibilities and control in relation to nonprofit schools. Their possibilities for influencing the schools are very limited, which, from a municipal point of view, might minimise the motivation for collaboration. Specifically, at a time when limited financial resources are available:

When a municipality has to plan efficient services in all fields - including schools - and we really need to do that in these years - it is a big challenge that one-third of the pupils are attending schools where we do not have any influence at all. (Administrative leader, DK, 8.10.2013) 
In contrast, there is a much higher degree of collaboration between municipalities and public schools-for instance, through formal leader meetings. One of the municipalities even has a common school council, where school boards from all schools in the municipalities are represented. According to the administrative leaders, the municipalities strive to involve the schools in important decisions-for instance, in the restructuring of school districts, the closing of schools, etc. (Interviews, administrative leaders, DK, 8.10.2013, 18.12.2013).

In Norway, collaboration between municipalities and nonprofit schools is also limited, apart from practical issues associated with the transportation of pupils as well as on decisions regarding extra resources to pupils with special needs. These pupils are assessed by municipal professionals, who decide whether special attention or extra resources should be provided. When the professionals make such a decision, the pupils are entitled to these resources at their schools and the municipality must pay, regardless of whether it is a public or nonprofit school.

This latter point can make it difficult for municipalities to plan their costs. One administrative leader talked about this issue and concluded that nonpublic schools are 'a hassle and annoyance' (Interview, administrative leader, $\mathrm{N}, 12.02 .2014)$. These steering challenges can be one explanation for the limited degree of collaboration.

However, some politicians actively embrace the nonprofit schools. The Conservative Party in Asker stated that it will 'develop cooperation with the nonprofits'. Challenged about how they would do this, their representative admitted that the tasks of the municipality are to 'make the operating conditions good enough so the schools want to continue. Yes, what we say is that we want to be positive towards the schools' (Interview, conservative politician, N, 22.10.2013). The inability of the politician to mention substantive steps the municipality could take to 'develop cooperation with nonprofits' illustrates the limited potential for collaboration between nonprofit schools and municipalities in Norway. The nonprofit schools provide schooling to a marginal fraction of citizens, and most interaction between the schools and the municipality is demanded and regulated by law.

However, one formal bond is that all nonprofit schools-according to the law-must have a school board responsible for their operation; and a 
representative from the municipality must be on the school board. This representative does not hold a vote but is entitled to meet and speak at all meetings. This representative is normally a politician involved in the school sector. This policy functions differently between the schools depending on the interest and efforts of individual politicians. The schools, therefore, report that some representatives are hardly ever seen at board meetings, while others make constructive contributions to the discussions.

Overall, there is little voluntary cooperation between nonprofit schools and the municipality. According to the analysis, this limited degree of collaboration can be explained by the lack of obvious areas for collaboration as well as the steering challenges experienced by the municipal actors. In contrast, collaboration between municipalities and public schools is more developed and includes both formal networks and meetings between school leaders and municipal administrators.

In Sweden, collaboration between municipalities and private schools is more common than in Denmark and Norway, although its level and content vary between the two case municipalities. In one of the municipalities, Sollentuna, private schools are included in several aspects. Three of the most striking examples of this have already been mentioned: First, the inclusion of private schools on a special website where citizens can make their own choice of school. Second, private schools have chosen to adopt local guidelines, which is a sort of collaboration with the municipality. Third, all schools in Sollentuna participate in a quality survey-targeting both parents and pupils-carried out by the municipality.

An additional element is the quality project Väga visa! (Dare to show!), which covers all schools. The project consists of school visits performed by teachers or other pedagogical leaders from neighbouring municipalities. Through these visits, attention is paid to how schools are working with different parts of national regulation such as learning, grading, norms and values, and pupils' influence. The information obtained from these visits is documented in a report summarising the strengths and weaknesses of the school (Interview, conservative politician, S, 13.12.2013).

Collaborations such as these do not exist in Östersund, but cooperation between public and private schools is not entirely absent. 
According to the Education Act, all pupils should be ensured access to school nurses and counsellors. In Östersund, private schools do not provide for this on their own, since they have been granted access to the public system. This is an important form of collaboration between private and public schools which does not exist in Sollentuna (Interview, school leader, nonprofit school, S, 8.4.2014).

In both municipalities, there is dialogue between the administration and the schools; for instance, on budget issues. This dialogue takes place in regard to all types of schools, but seems to be more comprehensive between the municipal administration and public schools. For example, in Sollentuna, all school leaders from public schools meet within a working group referred to as Rektorsgruppen to discuss joint efforts (Interview, school leader, S, 16.1.2014). A similar dialogue takes place between the administration and the public schools in Östersund. This indicates that the collaborative ties-also in the Swedish case-are stronger when it comes to public schools.

\section{Experiences at the School Level-Elements of Collaboration}

Also at the school level, the picture from the analysis above is clear. In all three countries, public school leaders perceive a higher degree of collaboration than private school leaders.

In the Danish case, nonprofit schools feel that a collaborative attitude on the part of the municipalities is limited. For instance, nonprofit schools do not have equal opportunities for attending municipal seminars, and relevant information, such as information about changes in bus timetables, does not always reach them (Interview, school leader, nonprofit school, DK, 9.1.2014). On the other hand, one of the public schools has the opinion that nonprofit schools receive too many of the same opportunities as public schools, since they do not have the same obligations (Interview, school leader, public school, DK, 9.1.2014).

A similar picture can be seen in Norway, where nonprofit schools feel ignored by the municipalities. They are in many instances not cooperatively included. Sometimes this is natural, since they operate on 
different terms, but all of the nonprofit schools would have preferred closer ties to the municipality (Interview, school leader, nonprofit school, N, 24.4.2014).

In Sweden, there are different views on the extent to which collaboration takes place with the municipal administration. In Östersund, a meeting with the administration is held twice a year. During these meetings, a discussion takes place on issues such as financial compensation and collaboration on health care for pupils (Interviews, school leaders, for-profit, S, 4.4.2014; nonprofit, S, 4.8.2014). In Sollentuna, similar meetings take place between the private school and the administration. Additionally, collaboration includes other types of activities, such as surveys and quality projects like Vaga visa! (Interview, school leader, for-profit, S, 3.4.2014). Private schools in Sweden experience a more collaborative attitude from the municipalities than nonprofit schools in Denmark and Norway.

In all three countries, municipalities appear to have a more collaborative attitude when it comes to public schools. School leaders of public schools believe that they are a more integrated part of the municipality than leaders of private schools. However, in the Danish case, the extent to which public schools actually feel involved and heard in decisions made by the municipalities, varies. In one of the municipalities, the public school perceives a limited degree of responsiveness, while there is a higher degree of satisfaction in the other municipality (Interviews, school leaders, DK, 9.1.2014, 14.3.2014; board members, DK, 26.2.2014, 30.4.2014).

\section{Summing up_Elements of Collaboration}

The results of the analysis of elements and degree of collaboration in the local governing of primary and lower secondary schools are summarised in Table 5.4.

As the table shows, the overall result of the analysis is that collaboration between municipalities and private schools is limited in all three countries. In Denmark, there are no formal meetings and limited contact, while in Norway there are few meeting points. Sweden stands out from the other countries by having some degree of collaboration between 
Table 5.4 Elements of collaboration in local governing of schools

\begin{tabular}{lll}
\hline & Elements of collaboration & $\begin{array}{l}\text { Degree of } \\
\text { collaboration }\end{array}$ \\
\hline $\begin{array}{c}\text { Denmark } \\
\text { Nonprofit } \\
\text { schools }\end{array}$ & No formal meetings and limited contact & Low \\
$\begin{array}{c}\text { Public } \\
\text { schools }\end{array}$ & Formal meetings and networks & Medium* \\
$\begin{array}{c}\text { Norway } \\
\text { Nonprofit } \\
\text { schools }\end{array}$ & Few meeting points & \\
$\begin{array}{c}\text { Public } \\
\text { schools }\end{array}$ & Formal meetings and networks & Low \\
$\begin{array}{c}\text { Sweden } \\
\text { Nonprofit } \\
\text { schools }\end{array}$ & Formal meetings, common guidelines*, common & Medium/Low* \\
$\begin{array}{c}\text { Public } \\
\text { schools }\end{array}$ & Formal meetings and networks & Medium \\
* Some variation between municipalities investigated &
\end{tabular}

municipalities and private schools. However, the content and degree of collaboration vary between the case municipalities. A number of factors can explain the limited degree of collaboration: For instance, the limited formal bonds and limited municipal opportunities for controlling and influencing the field of private schools. The competitive situation in some of the countries as well as financial pressures are also possible explanations. On the other hand, municipalities have more formal bonds to public schools. They are an integrated part of the municipal administration and therefore naturally collaborate more with the municipalities through formal meetings and networks.

\section{The Field of Schools-Between Control, Choice and Room for Distinctiveness}

What are the similarities and differences across countries and types of providers when it comes to municipal steering and regulation in the field of schools? What are the consequences for the schools? And finally, does 
the legislation and regulations promote or inhibit distinctive profiles at the schools?

The answer to these questions will provide the basis for a discussion of possible implications for future welfare provision in the field of schools in Scandinavia. Although the results of the case studies not necessarily can be generalised to all municipalities and schools in the three countries, the strength of the analysis is the in-depth character of the data, making it possible to identify mechanisms between the regulatory frameworks and the actions and experiences at the local level.

The overall picture from the analysis is that there are profound differences in the local governing of primary and lower secondary schools across private and public providers in the case municipalities. Moreover, national legislation is to a large extent reflected in the local governing of and attitudes towards different types of schools.

When it comes to elements related to control, there are similar trends across the Scandinavian countries. In general, administrative supervision in private schools is limited compared to public schools. Because of the national approval of private schools, municipalities have less direct control over them and limited steering possibilities, across all three countries. This goes furthest in Denmark and Norway, where municipalities have neither financial control nor quality control when it comes to nonprofit schools. It is up to national authorities to make sure that public support is used for educational purposes. In Sweden, municipalities have limited control through municipal budgets, but no control over the economy of private schools. They do have some potential control through different types of guidelines. However, it is voluntary for schools to join the common guidelines. Therefore, the extent of quality control varies between the Swedish municipalities.

These differences leave varying room for distinctiveness between the countries. The room for distinctiveness is particularly large in Denmark and Norway but less so in Sweden, where the same law regulates all schools. The municipal role in the national approval process also varies. In both Norway and Sweden, municipalities are heard when a private actor wishes to establish a school in the municipality, yet they have no veto power. In Denmark, it is an entirely national process. 
The limited degree of control is to some extent reflected in sceptical attitudes towards nonprofit schools from the municipal point of view. Again, this holds particularly true for Denmark and Norway. In spite of overall support for nonprofit schools, there is frustration regarding the steering challenges experienced. This is less evident in the Swedish case, where attitudes towards private schools are more a result of ideological positions than practical steering challenges. These ideological positions are also evident in Denmark, but to a lower extent than in Sweden, probably because of the opportunities for for-profit providers in Sweden and the long historical tradition of nonprofit providers in Denmark.

When it comes to elements of competition, there are some overall differences between the three countries. First, freedom of choice between all schools is defended by national legislation in both Denmark and Sweden. In Norway, opportunities for choice between public schools are largely a municipal decision, while it has always been possible to choose between public schools and nonprofit schools. Therefore, it is also possible to have competition in municipalities that - as in one of the case municipalities - have not implemented freedom of choice.

However, in the Norwegian case, the argument is that public and nonprofit schools attract different segments of the population and that there is, therefore, a low degree of competition and no municipal attempts to attract more pupils to public schools in the case municipalities. In contrast, there are clear signs of political interest in promoting public schools in both case municipalities in Denmark. In spite of general support for nonprofit schools, preventing the deselection of public schools is a primary ambition. In Sweden, municipalities are also aware of the competitive situation. However, the two case municipalities reacted in very different ways: One of the municipalities reacted by promoting transparency for parents in their choice of schools, while the other promoted public schools, similar to the Danish case municipalities.

Across the three Scandinavian countries, elements of collaboration are much more widespread in the relationship between municipalities and public schools than nonprofit schools. This is not surprising as public schools are a part of the municipal structure. There are, however, some differences across countries. The tendency is that collaboration between private schools and municipalities is closer in Sweden than in Norway 
and Denmark, where collaboration is very limited in the cases studied. However, also in Sweden, there is large variation across the case municipalities. In one of the municipalities, collaboration is limited to formal meetings, while there is more collaboration in the other municipality - for instance, through common guidelines and common surveys.

The case studies also show that the trends identified at the municipal level are to a large extent reflected at the school level. In all three countries, private providers perceive a large degree of freedom regarding the running of the schools, and this freedom is highly valued. In contrast, public schools experience a high and increasing degree of control, especially from the national level, but-particularly in Denmark-at the local level as well, although this varies between the case municipalities.

Regarding elements of competition, this is clearly experienced at the school level in both Denmark and Sweden. Whether the schools just accept the situation as it is or take specific actions to attract new pupils varies. In the Norwegian case municipalities, neither the schools nor the municipalities perceive nonprofit schools as competitors. However, this might be different in other local communities where private schools make particular public schools redundant.

Finally, regarding collaboration, perceptions are very similar to perceptions at the municipal level: Collaborative relations are more widespread when it comes to public schools than private schools. Nonprofit schools in both Denmark and Norway would like to have closer relations with their municipalities than is currently the case. In contrast, private schools in Sweden do have formal meetings with the municipality; and in one of the municipalities, private schools have voluntarily chosen to participate in more collaborative activities.

Altogether, the analysis shows important similarities between the three countries: Among the most important of these is the fact that the degree of municipal control is much lower when it comes to private schools than public schools. Another common trend is that there is a higher degree of collaboration between municipalities and public schools than nonprofit schools. However, there are also important differences, indicating that variation in national legislation, as described in detail in Chap. 3, is to a large extent reflected in actions and attitudes at the local level, in terms of both the municipal level and school level. 
First, sector distinctiveness varies between the countries. Sweden is the most marketised of the three Scandinavian countries given its opportunities for for-profit providers to establish schools. At the same time, Sweden has the largest degree of control and regulation over private schools, supporting the theoretical assumption that more market creates more regulation (Dølvik et al. 2015, 106). Second, the analysis shows a larger focus on equal services in Sweden than in Denmark and Norway, where nonprofit schools are often based on specific principles or values. In Norway, distinctiveness is even a criterion for establishing a nonprofit school. This leaves private schools in Sweden with less room for distinctiveness than in Norway and Denmark, which makes it more difficult for citizens to make an active choice between services with distinctive profiles. In relation to this, it is interesting that there are no significant differences between for-profit and nonprofit providers in Sweden when it comes to the local governing of schools.

Possible reasons for the identified differences across the Scandinavian countries can be found in different historical legacies. Both in Norway and Denmark, there has been a long historical tradition of nonprofit schools (Ibsen and Habermann 2006; Thuen and Tveit 2013). This historical tendency towards autonomy has remained very strong in spite of overall trends towards more regulation. In Sweden, the vast majority of primary and lower secondary schools has been under government control for many decades (Lundström and Wijkström 1995, 20); and until the 1990s, private schools only played a minimal role. The historical weight of equality in the Swedish welfare state (Bunar 2010, 56), together with newer trends of market principles, have been dominating the field of schools in Sweden, leaving less room for distinctiveness.

Altogether, the local governing of schools in Scandinavia does not show any clear signs of collaborative steering relations - at least not in the sense of dialogue and learning relations, which are some of the central characteristics of collaborative governance (Donahue and Zeckhauser 2011). Although the national steering of private providers can be characterised as indirect steering, where both the state and private providers influence the service provision (Segaard and Saglie, Chap. 3), collaborative steering relations at the local level are very limited. In relation to private schools, there is very limited collaboration, especially in Denmark 
and Norway, but also less control, leaving room for distinctiveness. When it comes to public schools, the control-based regime seems to be dominating, but there are elements of involvement and dialogue between municipalities and public schools.

The results of the analysis show a number of trade-offs worth discussing in relation to the implications of different types of welfare mix and local governing of different types of providers. These issues clearly show that the local governing of schools takes place in a complex mix of logics and tools from state, market and civil society.

First, there is a trade-off between the autonomy of schools and collaboration between schools and municipalities, particularly evident in Denmark and Norway. On the one hand, private schools value their independence and potential for developing a distinct profile. On the other hand, they would like to have more collaboration with the municipalities and be more accepted as alternative providers. In Sweden, private schools are to a larger extent integrated into the school system, but they also have less autonomy. However, there are local variations in the extent to which private schools are integrated.

Second, there is a related trade-off between equivalent quality and distinctiveness. Part of the reason why nonprofit schools are not fully accepted as an integrated part of the school system in Danish and Norwegian municipalities seems to be the clash between strong norms for equivalent quality and strong norms for autonomy and distinctiveness. In Sweden, another path has been chosen: A heavy focus on equivalent quality and services, resulting in less room for distinctiveness. Third, there is a trade-off between autonomy and accountability. When schools have a high degree of autonomy, tools for accountability are limited, which is the case in Norway and Denmark. Again, the situation in Sweden is different, because all schools are subject to the same law and have to follow the same national curriculum. This creates better possibilities for accountability, but less room for autonomy (Gustafsson et al. 2016, 56).

These points are interesting to discuss in relation to the role played by nonprofit actors in welfare services. The nonprofit sector is often-and has historically been — seen as a 'field of experimentation' and as providers of distinct, innovative and specialised services (Weisbrod 1977; 
Anheier 2009, 1092; Mariani and Cavanego 2013). However, possibilities for experimentation vary due to the level of control, and control is often implemented to ensure a legitimate accountability structure (Smith and Grønbjerg 2006).

The issues above are also relevant for the arguments surrounding the implementation of freedom of choice. One of the arguments is that citizens should be able to choose between different types of services (Petersen and Hjelmar 2013, 6). However, if the level of control is too high, it is clearly more difficult to have providers with a high degree of distinctiveness (Gustafsson et al. 2016, 48, 56). This paradox is particularly evident in the Swedish case: Although Sweden is the most marketised of the three countries, it is also the country with the least room for distinctiveness. With such a limited potential for distinctiveness, it can be debated whether citizens actually have real opportunities for choice which is a relevant point in the discussion of possibilities for active citizenship.

The country-specific differences above can be related to the fact that some of the Swedish private schools are run by for-profit actors, while all alternatives in Denmark and Norway are nonprofit schools. According to the classic literature, the non-distributional constraint is likely to create trust in nonprofit organisations (Hanssmann 1987), which might lead to lower demands for accountability. However, the high level of autonomy for nonprofit schools in Denmark and Norway also has to be seen in light of the long historical tradition of nonprofit organisations in these countries (Henriksen and Bundesen 2004; Ibsen and Habermann 2006; Thuen and Tveit 2013).

Altogether, the results of the case studies show that local governing in the field of primary schools largely reflects national legislation in the field. Moreover, local governing has clear implications for the local perceptions and actions of the schools. Finally, it is evident that there are large differences in the local governing of schools across public and private providers; to some extent, there are also variations between the three Scandinavian countries in spite of their other similarities, especially when it comes to the type of welfare regime. However, the results also suggest the institutional sector does not alone create the differences between the different types of providers. The complex interplay between regulation, 
funding and norms in the field are also of crucial importance. Together with local governing, national legislation has a large impact on the potential for distinctive services, accountability, equal quality and equal competition in the field of schools in Scandinavia. The balance between these elements is central to discuss in the future development of the welfare state in the three countries. In the concluding chapter, the importance of institutional legacies and political strategies for regulating the welfare mix and the distinctiveness of for-profit and nonprofit services will be further discussed.

\section{Notes}

1. www.friskoler.dk

2. In practice, this payment refers to a repayment of the block grant municipalities receive for each school-seeking child in the municipality (www.friskoler.dk).

\section{References}

Alber, Jens. 2010. What the European and American Welfare States have in common and where they differ: facts and fiction in comparisons of the European Social Model and the United States. Journal of European Social Policy 20 (2): 102-125.

Anheier, Helmut K. 2009. What Kind of Non-profit Sector? What Kind of Society? American Behavioral Scientist 52 (7): 1082-1094.

Arnesen, Anne-Lise, and Lisbeth Lundahl. 2006. Still Social and Democratic? Inclusive Education Policies in the Nordic Welfare States. Scandinavian Journal of Educational Research 50 (3): 285-300.

Baldersheim, Harald, and Lawrence E. Rose. (eds.). 2010. Territorial choice: The politics of boundaries and borders. Basingstoke: Palgrave Macmillan.

Bogason, Peter. 2001. Forvaltning og stat. Aarhus: Systime.

Bunar, Nihad. 2010. The controlled school market and urban schools in Sweden. Journal of School Choice 4 (1): 47-73.

Donahue, John, and Joseph Nye. 2002. Market-based governance. Brookings: Washington D.C. 
Donahue, Johna, and Richard Zeckhauser. 2011. Collaborative Governance. Princeton: Princeton University Press.

Dølvik, Jon Erik, T. Fløtten, J.M. Hippe, and B. Jordfald. 2015. The Nordic model towards 2030. A new chapter? Fafo report 2015:07. Oslo: Fafo.

Esping-Andersen, Gösta. 1990. The three worlds of welfare capitalism. Cambridge: Polity.

Evers, Adalbert and Helmut Wintersberger. 1990. Shifts in the welfare mix. Their impact on work, social services, and welfare policies. Frankfurt am Main: Campus Verlag.

Faaborg-Midtfyn Kommune. 2012. Børne-og Undervisningsudvalgets Årsplan 2012 [Annual calendar of the committee on children and education]. Denmark.

Gidron, Benjamin, Ralph M. Kramer, and Lester M. Salamon. 1992. Government and the third sector. San Francisco: Jossey-Bass Publishers.

Greve, Carsten and Niels Ejersbo. 2013. Udviklingen i styringen af den offentlige sektor. Baggrundspapir til Produktivitetskommissionen. Copenhagen Business School \& Syddansk Universitet.

Gustafsson, Jan-Eric, Sverker Sörlin, and Jonas Vlacos. 2016. Policyidéer för svensk skola. Stockholm: SNS Förlag.

Hansmann, H. 1987. Economic theories of non-profit organizations. In The Nonprofit Sector: A Research Handbook, ed. W.W. Powell, 27-42. New Haven: Yale University Press.

Henriksen, Lars Skov, and Peter Bundesen. 2004. The Moving Frontier in Denmark: Voluntary-State Relationships since 1850. Journal of Social Policy 33 (4): 605-625.

Henriksen, Lars Skov, Steven R. Smith, and Annette Zimmer. 2012. At the eve of convergence? Transformations of Social Service Provision in Denmark, Germany, and the United States. Voluntas 23 (2): 458-501.

Hood, Christopher 1991. A Public Management for All Seasons? Public Administration 69 (1): 3-19.

Homepage for Danish association for nonprofit schools. www.friskoler.dk.

Ibsen, Bjarne, and Ulla Habermann. 2006. De selvejende institutioner. In Frivillighed og nonprofit i Danmark - Omfang, organisation, økonomi og beskaftigelse, eds. Thomas Boje, and Bjarne Ibsen, 97-136. København: Socialforskningsinstituttet.

Jarl, Maria, and Linda Rönnberg. 2010. Skolpolitik: frän riksdagshus till klassrum. Stockholm: Liber.

Jørgensen, Torben Beck, and Karsten Vrangbæk. 2004. Det offentlige styringsunivers. Fra government til governance? Aarhus: Magtudredningen. 
Kersting, Norbert, and Angelika Vetter. 2003. Reforming Local Governments in Europe. Opladen: Leske + Budrik.

Law on independent and private schools (LBK 917 13/08/2014). Denmark.

Law on public schools (LBK 665 20/06/2014). Denmark.

Lundström, Tommy, and Filip Wijkström. 1995. Defining the non-profit sector: Sweden. Working Papers of the Johns Hopkins Comparative Non-profit Sector Project, no. 16. Baltimore: The Johns Hopkins Institute for Policy Studies.

Mariani, Laura, and Dario Cavenago. 2013. Redesigning welfare services for policies effectiveness: The nonprofit organizations' (NPOs) perspective. Public Management Review 15 (7): 1011-1039.

Meuleman, Louis. 2008. Public management and the metagovernance of hierarchies, networks and markets. The feasibility of designing and managing governance style combinations. Heidelberg: Physica-Verlag.

Nyhlén, Jon. 2013. Kommunen och skolmarknaden-Strategier och förhållningssätt. In När förvaltning blir business: - Marknadiseringens utmaningar för demokratin och välfärdsstaten, eds. L. Rönnberg, U. Strandberg, E. Wihlborg and U. Winblad, 153-168. Linköping: Linköping University Electronic Press.

Östersunds kommun (2013-11-28). Plan för kunskap och lärande. Östersund: Östersunds Kommun.

Pestoff, Victor A. 2009. A democratic architecture for the welfare state. Routledge, London \& New York.

Petersen, Ole Helby, and Ulf Hjelmar. 2013. Marketization of welfare services in Scandinavia: A review of Swedish and Danish experiences. Scandinavian Journal of Public Administration 26 (5): 3-20.

Phillips, Susan. D., and Steven R. Smith. 2011. Between governance and regulation. Evolving government-third sector relationships. In Governance and Regulation in the Third Sector. International Perspectives, eds. Susan D. Phillips and Steven R. Smith, 1-36. New York: Routledge.

Pollitt, Christopher, and Geert Bouckaert. 2011. Public management reform: A comparative analysis - new public management, governance, and the Neo-Weberian State. Oxford: Oxford University Press.

Powell, Martin A. 2007. Understanding the mixed economy of welfare. Policy Press.

Prop. 1991/92:25. Om valfrihet och fristående skolor [Government bill]. Sweden.

Prop. 2008/09:171. Offentliga bidrag på lika villkor [Government bill]. Sweden. 
Salamon, Lester M., and Stephan Toepler 2015. Government-non-profit cooperation: anomaly or necessity? Voluntas 26 (6): 2155-2177.

Seeleib-Kaiser, Martin, ed., 2008. Welfare state transformations: Comparative perspectives. Palgrave Macmillan.

Segaard, Signe Bock. 2015. Skole og eldreomsorg i Skandinavia. Nasjonale foringer for ikke-offentlige aktører. Rapport 2015:07. Oslo: Institutt for Samfunnsforskning.

Sivesind, Karl Henrik. 2007. Structured, qualitative comparison: Between singularity and single-dimensionality. In Data analysis, vol. 1, ed. Sotirios Sarantakos, 113-134. Los Angeles: Sage Publications.

Skolverket. 2014. Privata aktörer inom förskola och skola: En nationell kartläggning av enskilda huvudmän och ägare. Stockholm: Skolverket.

Smith, Steven. R., and Kirsten Grønbjerg. 2006. Scope and theory of government-non-profit relations. In The non-profit sector. A research handbook, eds. Walter W. Powell and Richard Steinberg, 221-242. London: Yale University Press.

Sollentuna kommun. 2008. Skolplan/utbildningsstrategi för Sollentuna kommun. Sollentuna: Sollentuna kommun. Adopted by the municipal council 2008-05-21.

Steinberg, Richard. 2006. Economic theories on nonprofit organizations. In The non-profit sector. A research handbook, eds. Walter W. Powell and Richard Steinberg, 117-139. London: Yale University Press.

Thelen, Kathleen. 2003. How institutions evolve. Insights from comparative historical analysis. In Comparative historical analysis in the social sciences, eds. James Mahoney and Dietrich Rueschemeyer, 208-240. Cambridge: Cambridge University Press.

Thuen, Harald, and Knut Tveit. 2013. Privatskolane: vere eller ikkje vere? Fire hundre år i motgang og medgang. Tidsskrift for samfunnsforskning 54 (4): 493-508.

Thøgersen, Malene. 2015. Explaining collaboration and commitment in Danish non-profit organizations: Linking institutional environments to outcomes. Voluntas 26 (5): 1639-1665.

Weisbrod, B.A. 1977. The voluntary non-profit sector, an economic analysis. Lexington, Mass: D.C. Heath.

Utdanningsdirektoratet. 2014. Utdanningsspeilet. Oslo. Utdanningsdirektoratet. 


\section{Author Biography}

Malene Thøgersen has a Ph.D. in Political Science from University of Southern Denmark. Today, she is a researcher at the Danish Institute for Non-formal Education, Aarhus. Her main research interests are the nonprofit sector and relations between the voluntary and the public sector, primarily at the local level. Her publications include articles in Scandinavian Political Studies and Voluntas, as well as contributions to a number of anthologies within the fields of local government reforms, voluntary associations, and sports policy.

Open Access This chapter is licensed under the terms of the Creative Commons Attribution 4.0 International License (http://creativecommons.org/licenses/by/ $4.0 /$ ), which permits use, sharing, adaptation, distribution and reproduction in any medium or format, as long as you give appropriate credit to the original author(s) and the source, provide a link to the Creative Commons license and indicate if changes were made.

The images or other third party material in this chapter are included in the chapter's Creative Commons license, unless indicated otherwise in a credit line to the material. If material is not included in the chapter's Creative Commons license and your intended use is not permitted by statutory regulation or exceeds the permitted use, you will need to obtain permission directly from the copyright holder.

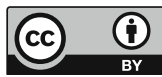

